
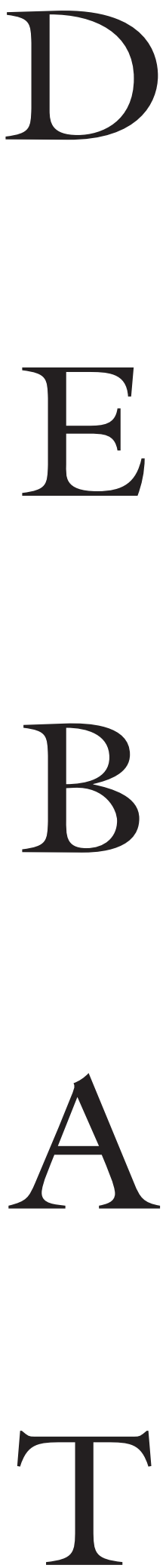

Debatstafet:

NAVNELEG:

identitetsstrategier på vej ind i det nye årtusinde

Kuinder, Køn og Forskning?

Foreningen for Kvinde- og

Kønsforskning? Eller Foreningen for Kønsforskning. Eller

...? Hvilke signaler sender foreningens og tidsskriftets navne, og er de dækkende? I forhold til hvad og hvem? Skal dobbeltbetegnelsen "køn og kvinde" fortsat profileres, eller skal "kvinde" udgå af såvel tidsskriftets navn som foreningens? Skal "køn" udgå? Beholder man sit fødenavn, eller skal der andre navne til døbefonten, når identiteten bevæger sig? Hvad er konsekvenserne af de forskellige strategier? Hvilke aktører, områder og strategier ekskluderes eller inkluderes i de forskellige navneforslag? Mænd? Børn? Minoriteter? Pluralisme og heterogenitet? Entydighed og fælles træk? Aflyser vi kvindeforskningen ved at fjerne dobbeltbetegnelsen, og hvor ligger solidariteten og bestræbelserne på empowerment?

Debattørerne i sidste nummer af Kvinder, Køn \& Forskning (Anette Borchorst, Cathrine Hasse og Helle Balsbye) gav stafetten videre til Nina Lykke, Pernille Tanggaard Andersen, Birgit Petersson, Anne Folke Henningsen og Cathrine Egeland. Vi bringer de tre førstnævntes indlæg i dette nummer og de to sidstnævnte i det kommende nummer, hvor navnelegen rundes af.
Pernille Tanggaard Andersen:

\section{BOR I}

\section{VORES NAVN}

\author{
Teg horer til dem, der mener, \\ at foreningen skal skifte navn \\ til Foreningen for Konsforsk- \\ ning $i$ Danmark.
}

J eg har ivrigt fulgt debatten om foreningens navn og er i den heldige situation at være blandt de sidste debattører.

Mit bidrag til debatten er præget af, at jeg er en yngre kvinde, som har haft kendskab til kvinde- og kønsforskningen igennem mit studie på AAU. Mit kendskab har dog meget bygget på eget initiativ, for selvom der sidder kompetente og ihærdige forskere indenfor kvinde- og kønsforskningsfeltet på AAU var dette forskningsfelt ikke en særlig tydelig del eller et højt prioriteret videnskabeligt område på min uddannelse i samfundsfag og sociologi. Det er derfor først i kraft af min ansættelse som Ph.d.-stipendiat på GEP-projektet og først indenfor de sidste to år, at forskningsmiljøet har fungeret som øjenåbner for en ny mangfoldig verden, stor empirisk bredde og teoretisk dybde. At jeg knytter an ved mine uddannelsesmæssige erfaringer, hænger sammen med $ø$ nsket om at kæde navnelegen til temaet for dette nummer af tidsskriftet, refleksioner over mainstreaming. De to debatter hænger på sin vis uløseligt sammen; det fælles udgangspunkt er, hvordan vi ser kvinde- og kønsforskningen i fremtiden, hvilken bredde vi ønsker, hvordan vi opfatter det fælles, det 'vi' som miljøet re- 
præsenterer og hvem 'vi' egentlig er? Foreningens navn symboliserer hvem 'vi' er og har en signalværdi ud ad til.

Jeg hører til dem, der men$\mathrm{er}$, at foreningen skal skifte navn til Foreningen for Kønsforskning i Danmark. På nuværende tidspunkt er der en bindestregsforbindelse i foreningens navn, og den har helt klart sin symbolske betydning. Der har ligget en bevidst strategi og positionering $\mathrm{i}$ bindestregsforbindelsen, men spørgsmålet er om navnet har samme slagkraft i dag, eller om navnet virker som en anakronisme? Forskning i kvinders vilkår og muligheder er stadig en yderst central del af forskningsfeltet og skal bestemt synliggøres og fortsætte, men ved fokusering på kønsforskning vægtes det relationelle, således at kvindelighed ses i relation til mandlighed, som magt ses i relation til afmagt. Jeg tilsutter mig derfor Hasses indlæg "at kønsforskning er forskning i forskel, der gør en forskel". Prioriteringen af kønsforskning som bærende i foreningens navn opfatter jeg, som tegn på rummelighed $\mathrm{i}$ forhold til forskningsområder i maskulinitet og seksualitet. Hvis foreningens navn skal afspejle feltets nuværende rummelighed, skulle mandeforskning vel også synliggøres i selve navnet, og det ville selvfølgelig være unødvendigt. Derfor virker kønsforskning som en mere præcis og dækkende betegnelse for feltet. I debatten om foreningens navn har argumentet mod et navneskift været, at forskningen ville mangle profil og blive køns- neutralt, og at et sådan navneskift var led i en mainstreamingstrategi om at komme i 'et bedre selskab'. Ud fra mit kendskab til forskningsfeltet frygter jeg ikke, at forskningen skal blive tandløs, og jeg ser ikke et navneskift som et garant for at komme i 'et bedre selskab', men derimod som en erkendelse af, at forskningsfeltet er præget af dynamik og foranderlighed.

I forhold til talen om 'det bedre selskab' må mainstreamingstrategier ses i et kønsperspektiv, og derfor handle om at ændre på 'det bedre selskabs' videnskabssyn ved at finde nye måder at tage magt på. Det gælder om at synliggøre kønsforskningsfeltet i videnskaberne. Mainstreaming af kønsforskningen skal ske på de præmisser 'vi' har opstillet og i relation hertil er det brændende nødvendigt, at 'vi' definerer hvem 'vi' er; hvordan opfattes rummelighed og solidaritet, hvilket også knytter an til navnestafetten.

Jeg plæderer for, at foreningen i fremtiden skal skifte navn til Foreningen for Kønsforskning. Men spørgsmålet er om tiden er moden? Navnestafetten er igennem sin korte levetid givet videre til kvindelige forskere; de yngre og de erfarne indenfor kvinde- og kønsforsknings miljøet. Stafetten er ikke givet videre til maskulinitetsforskere og til mænd. Jeg spørger mig selv hvorfor?

\section{Pernille Tanggaard Andersen} Ph.d.-stipendiat, GEP (Gender, Empowerment and Politics) $A A U / K U$

\section{Birgit Petersson: \\ FOKUS PA KVINDER!}

\author{
Teg har $i$ min tid som lege op- \\ levet mange instanser skifte \\ navn, fordi man sa troede, at \\ der ville forekomme mindre dis- \\ krimination, og at man kunne \\ komme med $i$ det pene selskab. \\ Det er, som om vi tror, at verden \\ bliver bedre, blot vi udskifter \\ navne.
}

elvfølgelig skal kvinder have
en fremtrædende plads i forhold til kvinde- og kønsforskningen. Jeg finder den nye mandsforskning meget spændende, men det rører for mig ikke ved den centrale problemstilling nemlig, at kvinders liv stadig er mangelfuldt beskrevet, og at kvinder stadig har en samfundsmæssig marginaliseret position. Der bliver samtidig i disse år gjort mere og mere for mænd i mandeforskningens og ligestillingens navn, uden at de meget væsentlige belastninger bedres for kvinder. Et iøjnefaldende område er enlige kvinder med børn, men også inden for sundhedsområdet kan der påvises store forskelle, bl.a. med alvorlige slidsygdomme hos ældre kvinder.

I den amerikanske sundhedsstyrelse besluttede man for nogle år siden, at der kun ville blive givet midler til forskningsprojekter, hvis køn og etnicitet var medinddraget $i$ undersøgelsesdesignet. Det betød i praksis, at kvinders forhold skulle medinddrages i forskningen, som næsten udelukkende havde handlet om mænd. Det skete, fordi det havde vist sig 
umuligt at ændre den eksisterende forskning ad anden vej end gennem pengepungen og efter mange opfordringer om at medindrage køn og etnicitet. Men også med stigende erkendelse af, at der ikke bare var store kønsforskelle, men også forskelle mellem racer/etniske grupper. Det sidste skete bl.a. fordi asiaterne er en mere og mere magtfuld gruppe i det amerikanske samfund i modsætning til den afroamerikanske befolkningsgruppe, der stadig har svært ved at gøre sin indflydelse gxldende. Det betyder naturligvis ikke, at der ikke udføres forskning, hvor kun det ene køn eller kun en bestemt race optræder, men det skal i så fald begrundes, hvorfor det sker.

Dette afspejler også forskellen mellem en humanistisk og en sundhedsvidenskabelig problemstilling. Inden for sundhedsvidenskab findes stadig store grupper, der totalt fornægter at andet end biologi spiller en rolle for sygdom og sundhed, mens der er en heldigvis voksende gruppe, der arbejder med det, der kaldes den bio-psyko-sociale model. Baggrunden for denne model er, at netop psykiske og sociale forhold påvirker biologien, men også at biologien påvirker både psykologiske og sociale forhold.

Den medicinske kvindeforskning opstod som en protest over, at kvinder enten var fraværende eller sygeliggjorte i den medicinske forskning. Store områder er i dag blevet afmystificeret, bl.a. Præmenstruel Syndrom (PMS) og Klimakteriet. Selv om det stadig kræver en kraftanstrengelse for, at disse forhold ikke sygeliggøres. Aktuelt forsøger praktiserende gynækologer med store midler fra medicinalindustrien, at behandle kvinder med PMS med de såkaldte Lykkepiller. Interessant bl.a. fordi der er store diskussioner i psykiaterkredse omkring der overhovedet findes et PMS, og at psykiaterne i øvrigt ikke har ønsket at medvirke. Vi ved, at de praktiserende læger i Danmark også ekstremt sjældent ser disse problemer og slet ikke blandt patienterne på de gynækologiske afdelinger.

Andre områder er kvinders generelle vilkår. Selv om der er sket ændringer, er der fortsat en lang række forhold, hvor kvinder er en underprioriteret eller fraværende gruppe. Ligesom det er vigtigt, at man fortsat arbejder på, at de to køn godt kan behandles ligeværdig, selv om de er forskellige.

Det er altså i høj grad nødvendigt at fastholde kvindeforskningen, som noget endda meget vigtigt.

Jeg har i min tid som læge oplevet mange instanser skifte navn, fordi man så troede at der ville forekomme mindre diskrimination, og at man kunne komme med i det pæne selskab. Jeg har været ansat på et "asyl", der senere blev et "statshospital", der senere blev til et "psykiatrisk hospital", der senere førte hen til "distriktpsykiatrien". Det er et navneskilt, der for brugerne, de psykiske syge, ikke har betydet mindre diskrimination og meget bedre forhold. Jeg har oplevet "idioter" skifte navn til "åndssvage", til “evnesvage” og siden "mentalt handicappede", uden det har ændret på det faktum at de lider af de samme skavanker. Det er, som om vi tror, at verden bliver bedre, blot vi udskifter navne, der kan virke provokerende $\mathrm{i}$ det pæne selskab. Og at ville fastholde kvindeforskningen virker provokerende i mange sammenhænge.

For nogle år siden brugte jeg betegnelsen kvindeligt og mandligt ved et videnskabeligt møde i Oslo, betegnelser som inden for psykoterapien er helt almindelige. De dækker over, at vi alle overtager dele af begge vores forældres adfærd og problemløsning, men også er påvirket af de stereotypier i samfundet, der er forbundet med det køn vi har fået med os fra fødslen. Vi kan i princippet, i hvert fald indtil vi făr børn, handle mandligt og kvindeligt i det omfang vi ønsker og har indlært, men når vi kommer ud i patologien handler de fleste, bortset fra mange skizofrene, enten som en karrikeret kvinde eller mand. Alligevel er det ofte provokerende at bruge sådanne betegnelser. I den pågxldende gruppe begyndte straks en diskussion om at de, kvinderne i gruppen, i hvert fald ikke ville måles på, at de var kvinder, og hvis de skulle ansættes, så skulle det være på kvalifikationer og ikke på køn. Jeg har aldrig forstået, hvorfor kvinder skal nedvurdere det at være kvinde.

I denne situation var det også meget sørgelig, for jeg oplevede gamle kvindeforskere svigte deres gamle holdninger - så vidt jeg kunne se, fordi de 
gerne ville være med i det pæne selskab. Det er ikke, fordi jeg ikke forstår, at man kan fristes til at bøje nakken for at få et arbejde, og man forsøger at gå med den strøm, der synes at have magt. Men jeg har aldrig på længere sigt set, at det var godt at svigte sine idealer, med mindre man kunne argumentere for, at der nu var sket så væsentlige ændringer at et forbehold eller lignende ikke var nødvendigt mere. Men så kan man jo være glad og stolt af processen. Man behøver så ikke at lægge afstand til sin gamle holdning.

Kort før Ligestillingsrådet sluttede sit arbejde afholdt de en konference om mænd. Pludselig hørte jeg formanden Ingrid Rasmussen sige at et meget vigtigt område var mænds middellevetid, der er nogle år lavere end kvinders. Det fik virkelig nakkehårene til at stritte hos mig. Ganske vist har jeg mødt enkelte sociologer uden særlig kendskab til biologiske forhold hos mennesker, anføre at det var mænds lave middellevetid i forhold til kvinders, der var det vigtigste forskningsområde. Men nu var det atter kvinder, der skulle favne mændene. Måske kan man forebygge lidt, og få øget middellevetiden hos mænd ved færre trafikulykker, arbejdsulykker hos fiskere og i fag, hvor mænd tager chancer, er overmodige, og derfor har en ret stor dødelighed, men det ændrer ikke på det forhold, at det primært er biologiske forhold, der gør sig gældende for mænds højere dødelighed af infektionssygdomme i barne- årene og hjertedødelighed i voksenårene, hvor kvinders tilsvarende dødelighed forskydes med 8-10 år. Nej, det store problem er, at danske mænd og især danske kvinders middellevetid er faldende i forhold til de øvrige europæiske lande - og her er det kvinderne, der udviser de mest alarmerende forhold. Men det glemte man, fordi man endnu engang skulle drage omsorg for "de stakkels drenge”, som børnepsykiateren Gideon Zlotnik kalder dem. Hvor blev kvinderne af?

Jeg håber, at jeg om ikke andet har givet et par eksempler på, at det er nødvendigt at fastholde fokus på kvinder mange år endnu.

Birgit Petersson, lektor, speciallage Afdelingen for Medicinsk kvinde- og kønsforskning, Institut for Folkesundhedsvidenskab, Københavns Universitet
Nina Lykke:

\section{LAD OS DROPPE PANHEDEN OG SPRINGE UD SOM FEMINISTISKE FORSKERE!}

Dat, jeg vil slå til lyd for er, osv. springer ud af det skab, der berer de delvist stuerene paiskrifter "kvinde-og kon-", for $i$ stedet at tage det politisk meget mere radikalt kritiske begreb "feminisme" på sig.

$\coprod \begin{aligned} & \text { vad skal foreningen, tids- } \\ & \text { skriftet osv. hedde? Som }\end{aligned}$ andre af navnelegens deltagere vil jeg tage udgangspunkt i en historisk betragtning over begreberne "kvindestudier/ forskning" og "kønsstudier/ forskning" og deres genealogiske rødder.

For 20 år siden var jeg med i den såkaldte Arbejdsgruppe for Kvindestudier - den gruppe, der i 1981 fik etableret det første danske kvindeforskningscenter, som i dag går under navnet "Center for Kvinde- og Kønsstudier” på Syddansk Universitet. Modellen for den organisation, vi dengang ønskede at skabe, var de amerikanske Centers for Women's Studies. Derfor var det $\mathrm{i}$ en vis forstand indlysende, at barnet skulle hedde "Center for Kvindestudier".

Der lå imidlertid også strategiske overvejelser bag. Eksistensen af de amerikanske centre betød, at vi kunne argumentere med, at der trods alt var forbilleder for det, vi ville. Det gav vores forehavende et minimalt skær af legitimitet hos de dybt skeptiske og mis- 
troiske universitetsmyndigheder. Vi kunne til en vis grad berolige dekan, fakultetsråd m.v. med, at nogle af deres ærværdige amerikanske kolleger faktisk havde sagt ja til at integrere det i manges øjne højst suspekte fænomen "kvindeforskning" i akademia. Foruden de amerikanske forbilleder havde vi også den trumf på hånden, at forskningsrådene herhjemme var begyndt at give støtte til seminarer om fænomenet. Det samfundsvidenskabelige Forskningsråd støttede f.eks. det første "kvindeforskningsseminar" på Sandbjerg Slot i 1978, arrangeret af kvinder på AUC.

Betegnelsen "kvindestudier" for de aktiviteter, som vores center på Odense Universitet skulle danne ramme om, blev valgt på den baggrund. Den var strategisk brugbar i forhold til de alt andet end begejstrede universitetsmyndigheder, som vi selvsagt ikke kunne komme udenom i navngivningen af en enhed, der var en del af universitetet, og hvis stillinger og aktiviteter skulle finansieres af dettes penge.

Dette leder mig frem til en bekendelse: Skulle jeg dengang i 1981 have valgt et navn uden skelen til, hvad der i datidens universitetsklima var muligt at få igennem, så skulle enheden helt klart have heddet "Center for feministiske studier". Ordet "kvindestudier" har - lige som den senere tilføjelse "kønsstudier" - for mig altid lagt et let slør af pænhed og legitimitet hen over det, jeg egentlig mente, det drejede sig om, nemlig dybtgående og grundlæggende feministisk kritik af videnskaben, videnskabsprocessen, videnskabskulturen og videnskabsorganiseringen. Derfor passede det mig også fint, da jeg - som medlem af Det Humanistiske Fakultetsråd - en del år senere fik indflydelse nok til at insistere på, at den engelske udgave af vores officielle navn blev "Department of Feminist Studies".

Med denne bekendelse om, at der lå et vist mål af strategisk legitimitetstænkning i valget af betegnelsen "Center for kvindestudier" frem for "Center for feministiske studier", vil jeg selvfølgelig på ingen måde fraskrive det synliggørelsesprojekt, som var en del af den tidlige kvindeforskning, dets kritiske og forskningsforandrede potentialer. At synliggøre kvinder i historien, litteraturen, samfundet, videnskaben, teknologiudviklingen osv. var og er for den sags skyld stadig - et betydningsfuldt forehavende. Men det har for mig altid været en del af et meget mere omfattende projekt, der handlede om et anderledes universitet, en anderledes videnskab og i videste forstand et anderledes samfund. Hvad det anderledes bestod i, var der ingen konsensus omkring blandt feministiske forskere og det var heller ikke pointen. Der var derimod tale om et projekt, der var drevet af en passioneret feministisk tro på det, som Donna Haraway i interviewet med hende andetsteds i dette nummer af Kvinder, Køn \& Forskning i tilknytning til Frankfurterskolens kritikbegreb omtaler som "the no-necessity of this way of doing the world". Det var også et pro- jekt, der handlede om andet og meget mere end blot og bar numerisk ligestilling mellem kvinder og mænd. Til gengæld var det, der engagerede mig og mange andre feministiske forskere, klart et projekt, der helt tilbage til begyndelsen af 1970erne involverede kønsrelationen. At det nu nærmest er blevet en kanoniseret "sandhed", at "kvindeforskningen" i 1970erne fokuserede på kvinder, og at kønskategorien og kønsforskningen blev opfundet i 1980erne, ændrer ikke på, at fokuseringen på kønsrelationen har stærke genealogiske rødder i diskussionen af forholdet mellem køn og klasse fra begyndelsen af 1970erne. En diskussion, der også i høj grad handlede om forholdet mellem feminisme og marxisme.

Det, jeg vil med denne historiske betragtning, er at slå til lyd for, at foreningen, tidsskriftet osv. springer ud af det skab, der bærer de delvist stuerene påskrifter "kvinde- og køn-", for i stedet at tage det politisk meget mere radikalt kritiske begreb "feminisme" på sig.

For at konkretisere, hvad denne ændring efter min opfattelse involverer, skal jeg opregne to af de vigtigste grunde til, at jeg f.eks. vil glæde mig over at være medlem af en Forening for feministisk forskning.

For det første mener jeg, at pænheden i dag har spillet fallit. I 1980erne havde brugen af ordet "kvindeforskning" effekt. Vi fik centre for kvindeforskning på universiteterne, og vi fik Folketingets Aktionsplan for Kvindeforskning. I 1990erne har både kvinde- og 
kønsforskning imidlertid talt for døve øren, og for at give genlyd skal "vi" (feministiske forskere) efter min opfattelse droppe pænheden og blive frækkere. Vi skal lytte mere den helt nye generation af feminister og (igen) udtrykke en feministisk passion, en feministisk vrede, en feministisk glæde, en feministisk vilje til noget andet. Det gælder i forhold til forskningen og universitetsverdenen, hvor modstanderne af kvinde- og kønsforskningen ofte taler i et stærkt nedgørende sprog, mens "vi" (feministiske forskere) svarer pænt og argumentativt. Desuden vil flere, bredere politiske markeringer bestemt heller ikke være af ve- jen. Hvorfor ikke i foreningens navn formulere et kritisk og kvalificeret modspil i debatten om kriminaliseringen af mødre, der insisterer på retten til at nægte opgive navnet på faderen, og til de mange koblinger mellem sexisme og racisme, som pressen flyder over med?

For det andet vil jeg glæde mig over at være medlem af en Forening for feministisk forskning, fordi det vil pointere en politisk radikalitet samtidig med, at det vil bringe foreningen ud over at definere sig med udgangspunkt i den ene eller den anden eller den tredje essentialiserende kønskategori. Endvidere åbner begrebet "feminisme", som det bruges af mange deltagere i den internationale teoridebat i dag, for et vigtigt fokus på positioneringer, der inkluderer intersektionaliteten mellem køn, etnicitet, klasse, alder, sexuel præference osv. Begrebet "feminisme" lægger på den måde åbent op til alliancer med andre typer kritisk politisk engageret forskning i sociokulturelt bårne magtforskelle. En forening, der arbejder med disse alliancer, vil jeg også meget gerne være medlem af.

Nina Lykke, prof., dr. phil. Center for Kvinde- og Konsstudier, Syddansk Universitet \& Tema Genus, Linköpings Universitet, Sverige 